\title{
THE LEADERSHIP ROLE OF CAMPUS MANAGERS TO IMPROVE STUDENT ACHIEVEMENT IN COLLEGES
}

\author{
P. Balkrishen* \\ e-mail: ceo@gsc4u.com

\section{R. Mestry*} \\ e-mail: rajm@uj.ac.za \\ * Department of Education Leadership and Management \\ University of Johannesburg \\ Johannesburg, South Africa
}

\section{ABSTRACT}

This study sought to identify successful leadership roles in campus managers and to better understand how these leadership roles and practices can improve student achievement in Further Education and Training (FET) colleges in South Africa. Improving the quality of FET colleges and student achievement is essential if these colleges are to meet the demands of skilling the youth for employment. The campus manager of an FET college is accountable for the quality of teaching and learning and consequently, student achievement. Using quantitative research, questionnaires were sent to the academic staff of all FET colleges in Mpumalanga. The study identified, using the multiple regression model, the most important predictors in student achievement in the National Certificate Vocational (NCV) examination in FET colleges. The results of the research also identified the leadership roles that are utilized by campus managers of high-achieving college campuses and conversely, also identified those areas that must be improved on for campus managers from poor performing college campuses. Replicating the leadership roles of campus managers of high performing colleges has the potential to impact on improving student achievement in FET colleges in South Africa.

Keywords: FET, Colleges, leadership, management, teaching and learning, student achievement, campus managers

\section{INTRODUCTION AND BACKGROUND TO THE PROBLEM}

The Further Education and Training (FET) college sector is currently inefficient in terms of throughput and retention rates, as well as certification rates (Cloete, Perold and Papier 2012, 63). Accordingly, this study seeks to identify successful leadership roles and practices in campus managers and to better understand how these leadership roles and practices can improve student achievement in FET colleges in South Africa.

Effective leadership and management are increasingly being regarded as essential for 
successful student achievement at all educational institutions, including FET colleges (Bush 2008, 8). The Department of Higher Education and Training (DHET) expresses similar sentiments to Bush, emphasising that without effective and efficient leadership, especially by campus managers, FET colleges will not be able to provide the high quality education and training that is needed for the college sector to expand and meet South Africa's skills needs (DHET 2013, 19). Improving the quality of FET colleges in South Africa, and consequently student achievement, is essential if FET colleges are to meet the demands of skilling the youth for employment (DHET 2013, 12). Cotton $(2003,1)$ claims that it would be difficult to find an educational researcher who does not believe that the head of the institution is critically important to the success of the institution, especially in terms of student performance. The researchers agree with Cotton (2003) and is of the opinion that the leadership role played by a campus manager is crucial in improving both the quality of FET colleges and student achievement.

The campus manager of an FET college plays a similar leadership role to that of a high school principal and is accountable for the quality of teaching and learning and student achievement (Deshmukh and Naik 2010, 154; McCaffery 2010, 20). Stronge, Xu and Leeper $(2013,58)$ concur and add that the fundamentally managerial role of the campus manager has evolved to include a leadership role with the ultimate goal of improving student learning. According to Leithwood, Louis, Wahlstrom and Anderson (2010, 3), one of the most important factors that influence student achievement in educational institutions, such as an FET college, is leadership. While the need for effective leadership in educational institutions is widely acknowledged, there is much less certainty about which specific leadership roles are most likely to improve instruction and student achievement (Bush 2008, 391; Leithwood and Louis 2011, 27).

\section{RATIONALE FOR THIS STUDY}

Vocational education and training has long been recognised as a vehicle for providing a route out of poverty for unemployed individuals and as a way of promoting equality of opportunity (DHET 2013, 5). Leithwood et al. (2010, 7) concur with this view and emphasise that education and training is widely regarded as being crucial for the success of individuals and countries and, thus, research on successful educational leadership has great social justification.

One of the key problems in colleges is that not enough is known about exactly what makes an individual effective as a leader and what, in turn, may make them ineffective (Bryman 2007, 14). The report of the Systemic Audit of FET colleges in the Eastern Cape asserts that there is 
limited research available that provides a nuanced picture of the college system and of its strengths and weaknesses (DHET 2010, 9). The scarcity of empirical data on educational leadership in FET colleges in South Africa is especially disconcerting in view of the strategic importance of the sector and the poor performance of FET colleges. This study seeks to address that part of the research gap which explores the relationship between the leadership role of the campus manager and the impact the campus manager has on teaching and learning and, subsequently, student achievement in FET colleges in Mpumalanga province.

The researchers deem this research as being significant in that it proposes to identify core leadership roles and practices that can be applied by campus managers in FET colleges to improve their leadership effectiveness and efficacy so that, subsequently, the quality of teaching and learning and student achievement progresses. Improved student performance can change the negative perceptions that surround FET colleges, which, in turn, can improve student employability prospects. Subsequently, this study proposes the following research question: What leadership role do campus managers play in FET colleges in Mpumalanga province in improving student achievement?

This study aims to explore the leadership role of campus managers at FET colleges in Mpumalanga province and the way in which it improves student achievement. The following objectives encapsulate this study:

- To determine the perceptions of lecturers on how campus managers bring about academic performance improvement at FET colleges.

- To identify which core leadership roles and practices of campus managers influence student achievement at FET colleges.

- To strengthen the role of campus managers in leading teaching and learning effectively and consequently managing student achievement at FET colleges better.

\section{CORE LEADERSHIP PRACTICES AND STUDENT ACHIEVEMENT}

Grogan (2013, 83) argues that effective educational leaders promote better teaching. Furthermore, the Organisation for Economic Co-operation and Development (OECD) report $(2011,5)$ states that leadership matters because leaders, such as campus managers, play a key role in improving campus outcomes by influencing the motivations and capacities of teachers, as well as the campus climate and environment. The report on the Systemic Audit of FET colleges in the Eastern Cape (DHET 2010, 19) points out that in world-class organisations, excellent leaders facilitate the development, adoption and implementation of the mission and 
vision; they develop the values required for the long-term success of the organisation and implement these by means of appropriate actions and behaviours.

This study explores whether the core leadership roles identified by Hallinger (2003), Cotton (2003), Leithwood, Louis, Wahlstrom and Anderson (2004), Marzano, Waters and McNulty (2005) and McCaffery (2010), such as setting direction, developing staff, developing the organisational culture and managing the instructional programme, are perceived to assist campus managers to improve student academic achievement in FET colleges in Mpumalanga The theoretical framework, as illustrated in Figure 1, provided the basis upon which the entire study was conducted.

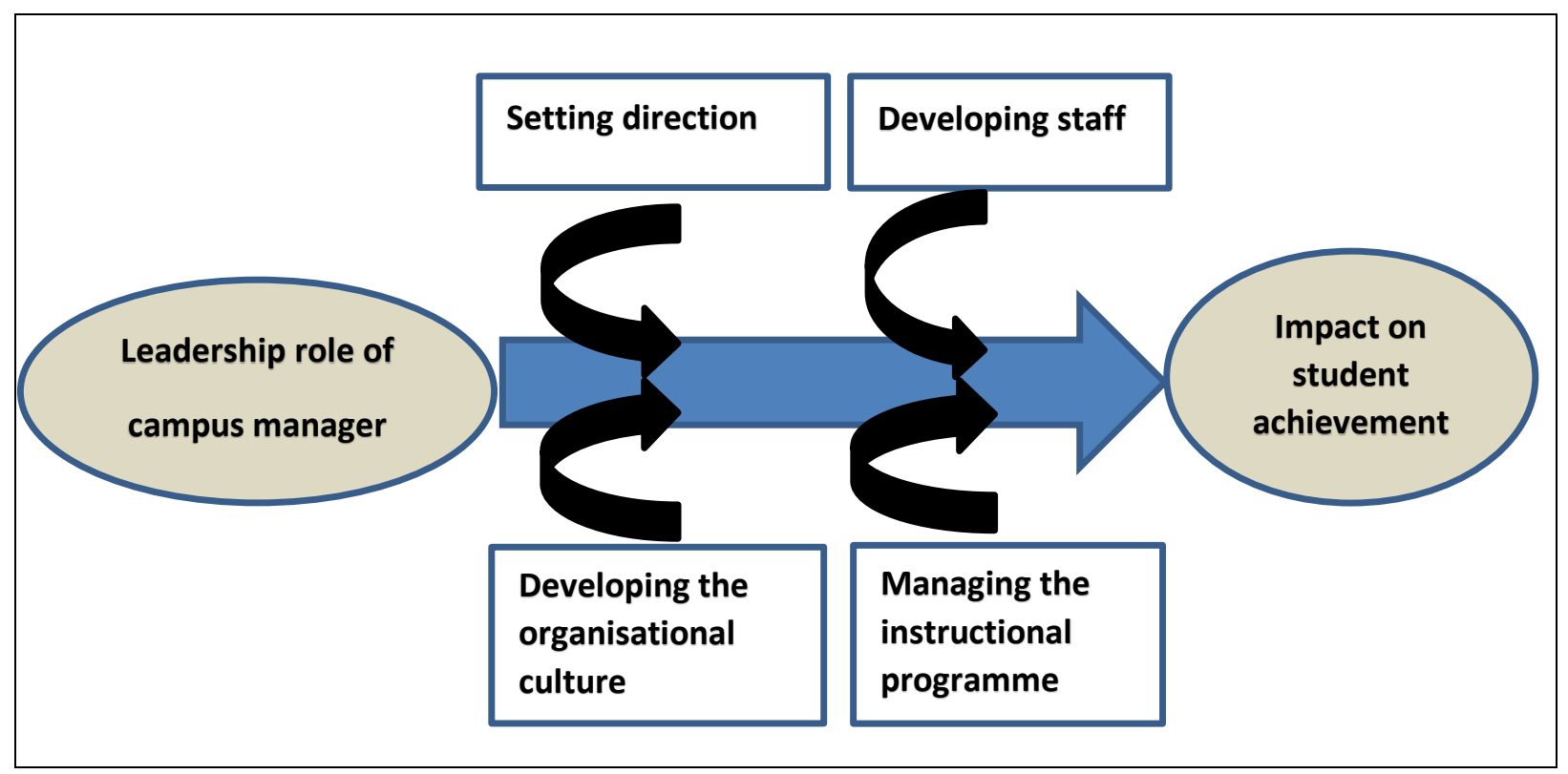

Figure 1: Leadership roles and practices and their impact on student achievement (Source: Developed by researchers)

Previous studies in the field of educational leadership and student achievement such as those by Danielson (2002) and Jackson (2013) have focused almost exclusively on schools. However, despite the increased relevance of FET college education across the world, and acknowledging that the role of the high school principal and campus manager of a FET college regarding student achievement are very similar in nature (Deshmukh and Naik 2010, 154), limited empirical research has been conducted on FET colleges, especially from the perspective of the leadership role of the campus manager and how this role impacts on student achievement.

While the need for effective educational leadership is widely acknowledged, there is much less certainty about which leadership roles are most likely to produce improved student achievement (Bush 2008, 391). The literature review focuses extensively on the core leadership 
roles and practices that are linked to improving student achievement drawing mainly on the research conducted by Cotton (2003), Hallinger (2003), Leithwood et al. (2004), Marzano et al. (2005) and McCaffery (2010). A comparative analysis of the findings of these researchers indicate a great overlap amongst the leadership roles and practices that they identified which are linked to student achievement.

The research conducted by Leithwood et al. (2004, 8), provides compelling evidence of a common core set of leadership roles and practices that are necessary for successful educational leaders and that these are applicable across different organisations, from different parts of the world with different national cultures. According to Leithwood and Louis, (2011, 59), student achievement is influenced by the following categories of core leadership practices:

- $\quad$ setting direction (Table 1)

- $\quad$ developing staff (Table 2)

- $\quad$ developing the organisational culture (Table 3)

- $\quad$ managing the instructional programme (Table 4).

Rather than prescribing a blueprint, these four leadership categories identified by Leithwood et al. $(2011,59)$ provides the theoretical framework for this study and a useful lens to reflect on the various leadership roles identified by Cotton (2003), Hallinger (2003), Leithwood et al. (2004), Marzano et al. (2005) and McCaffery (2010).

The literature review discussed each of the leadership roles that can improve student achievement in detail. Student achievement, for the purposes of this study, will be limited to academic performance of FET college students in external assessments such as the National Certificate Vocational (NCV) examinations.

\section{Setting direction}

This category of leadership roles and practices (see Table 1) comprises specific practices such as: develops a vision and mission, sets clear goals and targets, and creates high performance expectations (Leithwood et al. 2011, 59). Middlewood and Lumby $(2013,22)$ suggest that the direction of the campus should be institutionalised so that it shapes the everyday activities of the campus. In South Africa, where the core business of the FET college should be to provide high-quality teaching and learning to improve student achievement, the campus manager has an important leadership role in ensuring that all activities support this core business.

Table 1: Comparison of core leadership practices: setting direction 


\begin{tabular}{|c|c|c|c|c|}
\hline $\begin{array}{l}\text { Cotton } \\
(2003)\end{array}$ & $\begin{array}{l}\text { Hallinger } \\
(2003)\end{array}$ & $\begin{array}{l}\text { Leithwood et al. } \\
\text { (2004) }\end{array}$ & $\begin{array}{l}\text { Marzano et al. } \\
(2005)\end{array}$ & $\begin{array}{l}\text { McCaffery } \\
(2010)\end{array}$ \\
\hline \multicolumn{5}{|c|}{ Setting direction } \\
\hline Builds vision & $\begin{array}{l}\text { Developing a } \\
\text { clear mission }\end{array}$ & $\begin{array}{l}\text { Building a shared } \\
\text { vision }\end{array}$ & $\begin{array}{l}\text { Inspires and leads new } \\
\text { and challenging } \\
\text { innovations }\end{array}$ & $\begin{array}{l}\text { Develops a clear } \\
\text { vision and strategic } \\
\text { direction }\end{array}$ \\
\hline $\begin{array}{l}\text { Sets clear } \\
\text { learning goals }\end{array}$ & $\begin{array}{l}\text { Framing the } \\
\text { institution's goals }\end{array}$ & $\begin{array}{l}\text { Fostering the } \\
\text { acceptance of group } \\
\text { goals }\end{array}$ & $\begin{array}{l}\text { Establishes clear goals } \\
\text { and keeps them in } \\
\text { forefront of all } \\
\text { stakeholders' attention }\end{array}$ & $\begin{array}{l}\text { Sets direction for } \\
\text { achieving goals }\end{array}$ \\
\hline $\begin{array}{l}\text { Focuses on } \\
\text { student learning }\end{array}$ & $\begin{array}{l}\text { Communicating } \\
\text { the institution's } \\
\text { goals }\end{array}$ & $\begin{array}{l}\text { Communicating the } \\
\text { direction }\end{array}$ & & \\
\hline $\begin{array}{l}\text { High } \\
\text { expectation for } \\
\text { learning for all } \\
\text { students }\end{array}$ & $\begin{array}{l}\text { Focused on } \\
\text { students' } \\
\text { academic } \\
\text { progress }\end{array}$ & $\begin{array}{l}\text { Creating high } \\
\text { performance } \\
\text { expectations }\end{array}$ & & $\begin{array}{l}\text { High performance } \\
\text { so as to compete at } \\
\text { national and } \\
\text { international level }\end{array}$ \\
\hline
\end{tabular}

Source: Adapted from Leithwood et al. (2011)

\section{Developing people}

The ultimate goal of professional development in educational institutions is to increase student learning (Stronge, Richard and Catano 2008, 50). This category of leadership roles and practices (refer to Table 2) comprises specific practices which the campus manager can use to develop staff such as: promoting professional development, recognising and rewarding achievement, providing interpersonal support, practicing open communication, and maintaining high visibility and accessibility. The primary aim of these leadership roles and practices is to build the capacity of staff which are necessary for them to accomplish the goals of the institution such as improved student achievement (Leithwood, Day, Sammons and Hopkins 2006, 36).

Table 2: Comparison of core leadership practices: developing people

\begin{tabular}{|c|c|c|c|c|}
\hline $\begin{array}{l}\text { Cotton } \\
\text { (2003) } \\
\end{array}$ & $\begin{array}{l}\text { Hallinger } \\
(2003)\end{array}$ & $\begin{array}{l}\text { Leithwood et al. } \\
(2004)\end{array}$ & $\begin{array}{l}\text { Marzano et al. } \\
(2005)\end{array}$ & $\begin{array}{l}\text { McCaffery } \\
(2010)\end{array}$ \\
\hline \multicolumn{5}{|c|}{ Developing people } \\
\hline \multirow[t]{2}{*}{$\begin{array}{l}\text { Emotional and } \\
\text { interpersonal } \\
\text { support }\end{array}$} & $\begin{array}{l}\text { Providing } \\
\text { incentives for } \\
\text { teachers }\end{array}$ & $\begin{array}{l}\text { Providing } \\
\text { individualised } \\
\text { support and } \\
\text { consideration } \\
\text { Emotional } \\
\text { understanding and } \\
\text { support }\end{array}$ & $\begin{array}{l}\text { Recognises and } \\
\text { rewards individual } \\
\text { accomplishment } \\
\text { Demonstrates } \\
\text { awareness of } \\
\text { personal aspects of } \\
\text { teachers and staff }\end{array}$ & $\begin{array}{l}\text { Reward systems in } \\
\text { place } \\
\text { Pay and reward } \\
\text { framework } \\
\text { Inspires trust } \\
\text { Displays emotional } \\
\text { intelligence }\end{array}$ \\
\hline & $\begin{array}{l}\text { Promoting } \\
\text { professional } \\
\text { development }\end{array}$ & $\begin{array}{l}\text { Offering intellectual } \\
\text { stimulation }\end{array}$ & $\begin{array}{l}\text { Is willing to and } \\
\text { actively challenges } \\
\text { the status quo } \\
\text { Ensures faculty and } \\
\text { staff are well } \\
\text { informed about best } \\
\text { practice/fosters } \\
\text { regular discussion of } \\
\text { them }\end{array}$ & $\begin{array}{l}\text { Develops staff } \\
\text { Emphasises } \\
\text { continuous } \\
\text { professional } \\
\text { development } \\
\\
\text { Enhances } \\
\text { motivation }\end{array}$ \\
\hline Open & Maintaining high & Modelling & Has quality contacts & Makes a personal \\
\hline
\end{tabular}




\begin{tabular}{|c|c|c|c|c|}
\hline $\begin{array}{l}\text { Cotton } \\
(2003) \\
\end{array}$ & $\begin{array}{l}\text { Hallinger } \\
(2003)\end{array}$ & $\begin{array}{l}\text { Leithwood et al. } \\
(2004)\end{array}$ & $\begin{array}{l}\text { Marzano et al. } \\
(2005)\end{array}$ & $\begin{array}{l}\text { McCaffery } \\
(2010)\end{array}$ \\
\hline \multicolumn{5}{|l|}{ Developing people } \\
\hline $\begin{array}{l}\text { communication and } \\
\text { interaction } \\
\text { High visibility and } \\
\text { accessibility }\end{array}$ & visibility & $\begin{array}{l}\text { appropriate values } \\
\text { and practices }\end{array}$ & $\begin{array}{l}\text { and interactions with } \\
\text { teachers and } \\
\text { students }\end{array}$ & $\begin{array}{l}\text { impact and leads by } \\
\text { example } \\
\text { Manages staff } \\
\text { performance }\end{array}$ \\
\hline
\end{tabular}

Source: Adapted from Leithwood et al. (2011)

\section{Developing the organisational culture}

This category includes the leadership roles and practices of the campus manager in building a collaborative institutional culture, encouraging shared decision making, fostering teamwork and consultation, seeking continuous improvement, promoting risk taking, innovation and creativity, and connecting to the wider college community (refer to Table 3). The core business of schools and FET colleges is teaching and learning, and one of the most important tasks of the manager is to create an organisational culture that is conducive to student achievement (Republic of South Africa (RSA) 2013, 303).

Although the effects of leadership in developing the organisational culture may not directly affect student achievement, it does create a climate in the institution that is conducive to high quality teaching and learning and student success (Leithwood et al. 2011, 14-15). The definition of organisational culture by Bush and Coleman $(2000,42)$ captures the essence of this important concept as the characteristic spirit and belief of an organisation, demonstrated, for example, in the norms and values that are generally held about how people should treat each other, the nature of working relationships that should be developed and attitudes to change. Deshmukh and Naik (2010, 125) views the organisational culture as an organisation's personality.

Leithwood et al. $(2011,59)$ suggest that developing an appropriate organisational culture will establish workplace conditions that will enable staff members to make optimal use of their capacities. Deshmukh and Naik $(2010,125)$ proposes that an effective FET college campus culture is one in which the customs and values foster success for all and where clear boundaries are set, known and agreed to by everyone. Leithwood et al. $(2011,59)$ contend that staff are motivated when they believe the organisational culture is supportive of creating optimum conditions in the classroom that will augment the quality of instruction.

The campus manager is responsible for developing, advocating, and sustaining an academically rigorous organisational culture for all stakeholders so that student achievement is enhanced (Stronge et al. 2013, 26; Grogan 2013, 83).

Table 3: Comparison of core leadership practices: developing the organisational culture 


\begin{tabular}{|c|c|c|c|c|}
\hline $\begin{array}{l}\text { Cotton } \\
\text { (2003) }\end{array}$ & $\begin{array}{l}\text { Hallinger } \\
(2003)\end{array}$ & $\begin{array}{l}\text { Leithwood et al. } \\
(2004)\end{array}$ & $\begin{array}{l}\text { Marzano et al. } \\
(2005)\end{array}$ & $\begin{array}{l}\text { McCaffery } \\
(2010)\end{array}$ \\
\hline \multicolumn{5}{|c|}{ Developing the organisational culture } \\
\hline $\begin{array}{l}\text { Building an } \\
\text { institutional culture } \\
\text { that encourages } \\
\text { shared leadership } \\
\text { and decision- } \\
\text { making } \\
\text { Fosters } \\
\text { collaboration } \\
\text { Expects continuous } \\
\text { improvement }\end{array}$ & $\begin{array}{l}\text { Providing } \\
\text { incentives for } \\
\text { learning }\end{array}$ & $\begin{array}{l}\text { Building a } \\
\text { collaborative } \\
\text { culture }\end{array}$ & $\begin{array}{l}\text { Fosters shared beliefs, } \\
\text { sense of community, } \\
\text { cooperation } \\
\text { Recognises and } \\
\text { celebrates institutional } \\
\text { accomplishments } \\
\text { Involves teachers in the } \\
\text { design and } \\
\text { implementation of } \\
\text { important tasks }\end{array}$ & $\begin{array}{l}\text { Inspiring staff to } \\
\text { work together and } \\
\text { give of their best } \\
\text { Leads learning } \\
\text { communities, } \\
\text { creating the } \\
\text { conditions to foster } \\
\text { creativity } \\
\text { Seeks continuous } \\
\text { improvement }\end{array}$ \\
\hline $\begin{array}{l}\text { Community } \\
\text { outreach and } \\
\text { involvement }\end{array}$ & & $\begin{array}{l}\text { Connecting the } \\
\text { institution to the } \\
\text { wider community }\end{array}$ & $\begin{array}{l}\text { Is an advocate and } \\
\text { spokesperson for the } \\
\text { institution to all } \\
\text { stakeholders }\end{array}$ & $\begin{array}{l}\text { Connecting the } \\
\text { institution to } \\
\text { stakeholders and } \\
\text { partners }\end{array}$ \\
\hline
\end{tabular}

Source: Adapted from Leithwood et al. (2011)

\section{Managing the instructional programme}

This is the final category (Table 4) and arguably the most important as compared with the three previous categories as it directly shapes the quality of teaching and learning and student achievement (Leithwood et al. 2011, 59). This category includes the campus manager's leadership role in assessment, knowledge of the curriculum, monitoring and evaluating instruction, providing instructional support, providing resources, protecting instructional time, using data, and monitoring student progress. A close correlation exists between these leadership roles and practices, and the instructional leadership model as they are both aimed at improving teaching and learning (Stronge et al. 2013, 20). Jackson $(2013,135)$ shares similar sentiments as Stronge et al. (2013) and adds that instructional leaders make mastery of instruction more appealing to staff and help create a rigorous and supportive instructional climate where good teaching and learning can thrive.

Table 4: Comparison of core leadership practices: managing the instructional programme

\begin{tabular}{|c|c|c|c|c|}
\hline $\begin{array}{l}\text { Cotton } \\
(2003)\end{array}$ & $\begin{array}{l}\text { Hallinger } \\
(2003)\end{array}$ & $\begin{array}{l}\text { Leithwood et al. } \\
(2004)\end{array}$ & $\begin{array}{l}\text { Marzano et al. } \\
(2005)\end{array}$ & $\begin{array}{l}\text { McCaffery } \\
(2010)\end{array}$ \\
\hline \multicolumn{5}{|c|}{ Managing the instructional programme } \\
\hline $\begin{array}{l}\text { Discussing } \\
\text { instructional } \\
\text { issues } \\
\text { Supporting } \\
\text { teacher autonomy }\end{array}$ & $\begin{array}{l}\text { Supervising and } \\
\text { evaluating } \\
\text { instruction } \\
\text { Coordinating the } \\
\text { curriculum }\end{array}$ & $\begin{array}{l}\text { Providing staffing } \\
\text { and instructional } \\
\text { support }\end{array}$ & $\begin{array}{l}\text { Establishes set of } \\
\text { standard operating } \\
\text { procedures for } \\
\text { teaching and learning } \\
\text { Directly involved in } \\
\text { instruction and } \\
\text { assessment practices }\end{array}$ & $\begin{array}{l}\text { Focus on learning, } \\
\text { teaching and } \\
\text { curriculum } \\
\text { Trusts staff to take } \\
\text { decisions } \\
\text { Tackles poor } \\
\text { performance }\end{array}$ \\
\hline $\begin{array}{l}\text { Observing } \\
\text { classrooms and } \\
\text { giving feedback } \\
\text { Monitoring }\end{array}$ & $\begin{array}{l}\text { Monitoring } \\
\text { student progress }\end{array}$ & $\begin{array}{l}\text { Monitoring } \\
\text { progress of } \\
\text { students, teachers } \\
\text { and the institution }\end{array}$ & $\begin{array}{l}\text { Monitors the } \\
\text { effectiveness of } \\
\text { institutional practices } \\
\text { and their impact on }\end{array}$ & $\begin{array}{l}\text { Quality assurance } \\
\text { Measures teaching } \\
\text { effectiveness } \\
\text { Giving feedback to }\end{array}$ \\
\hline
\end{tabular}




\begin{tabular}{|c|c|c|c|c|}
\hline $\begin{array}{l}\text { Cotton } \\
(2003) \\
\end{array}$ & $\begin{array}{l}\text { Hallinger } \\
(2003)\end{array}$ & $\begin{array}{l}\text { Leithwood et al. } \\
\text { (2004) }\end{array}$ & $\begin{array}{l}\text { Marzano et al. } \\
(2005)\end{array}$ & $\begin{array}{l}\text { McCaffery } \\
(2010)\end{array}$ \\
\hline \multicolumn{5}{|c|}{ Managing the instructional programme } \\
\hline $\begin{array}{l}\text { progress and } \\
\text { using student } \\
\text { progress data for } \\
\text { programme } \\
\text { improvement }\end{array}$ & & Aligning resources & $\begin{array}{l}\text { student learning } \\
\text { Provides resources } \\
\text { necessary for the job }\end{array}$ & $\begin{array}{l}\text { staff } \\
\text { Sets targets and } \\
\text { monitors progress }\end{array}$ \\
\hline $\begin{array}{l}\text { Protecting } \\
\text { instructional time }\end{array}$ & $\begin{array}{l}\text { Protecting } \\
\text { teaching time }\end{array}$ & $\begin{array}{l}\text { Buffering staff from } \\
\text { distractions in their } \\
\text { core work }\end{array}$ & $\begin{array}{l}\text { Protects teachers from } \\
\text { influences that would } \\
\text { detract from their } \\
\text { teaching time or focus }\end{array}$ & $\begin{array}{l}\text { Risk management } \\
\text { plans in place }\end{array}$ \\
\hline
\end{tabular}

Source: Adapted from Leithwood et al. (2011)

\section{RESEARCH METHODOLOGY}

The positivist approach employed led to a survey research design being chosen. Questionnaires were used as the instrument for collecting the data required to determine the perceptions of academic staff at FET colleges on the leadership roles of their campus managers regarding student achievement. The questionnaire was divided into two sections namely; Section A and Section B. In Section A, the biographical details of the respondents was required. In Section B, 44 items were designed to determine the perceptions of respondents related to the study. The closed-ended items that were constructed for Section B were based on key factors that were identified during the literature review as having an influence on campus leadership and management. Based on a five-point Likert scale, respondents were required to indicate the extent to which they agreed or disagreed with statements concerning leadership at their campuses. Since the study was linked to the perceptions of staff of the leadership role of the campus manager and how this influences student achievement, the population chosen for this study were the staff that are linked to curriculum delivery in all three FET colleges in Mpumalanga. This included the campus manager, heads of division (HODs), senior lecturers and lecturers. If one were to group campus managers, heads of division and senior lecturers together under management, as they are more concerned with management tasks, then 19.2 per cent of the sample could be classified as management while lecturers formed 72.7 per cent of the sample. Thus, there are approximately four lecturers for every one staff member in management, which is reasonably representative of FET colleges on the whole.

Although it was initially planned to use clustered sampling upon the advice of experts from Statkon, the sample was extended to the entire population which included 16 college campuses instead of the originally planned nine. Only 15 FET college campuses participated in the final survey as one campus was not considered as it was randomly selected for the pilot study.

Three hundred and fifty-seven respondents (61,5\%) completed the survey instrument with 
118 from College A, 130 from College B and 109 from College C. The respondents' ages ranged from 22 to 67 years, with 54 per cent being female and 46 per cent male. Of the 357 respondents, the majority were lecturers (73\%) while 19 per cent were from campus management.

One of the main reasons for selecting all three colleges in Mpumalanga is that there was significant variance in the academic performance of each college (refer to Table 5). This spread in the performance of the population increases the external validity of the research to enable it to be extended to FET colleges across South Africa. As the national average certification rate for FET colleges in 2013 was 42 per cent (DHET 2013, xii), the population included College A (with a certification rate of 34\%) that was significantly below the national average, College B (with a certification rate of $42 \%$ ) that was equal to the national average and College $C$ (with a certification rate of 59\%) that was significantly above the national average as reflected in Table 5.

Table 5: Academic performance of FET colleges in 2013

\begin{tabular}{|l|l|}
\hline Mpumalanga FET colleges & Average certification rate in 2013 examinations \\
\hline College A & $34 \%$ \\
\hline College B & $42 \%$ \\
\hline College C & $59 \%$ \\
\hline
\end{tabular}

(Source: DHET 2014: 1)

The data was analysed by the statistical services unit of the university. The responses of participants were captured on Statistics Package for the Social Sciences (SPSS) version 22.0. A statistical technique called factor analysis was used to estimate the construct validity of the questions that make up the scales. This technique conveys the extent to which the questions seem to be measuring the same concepts or variables (Glen 2010, 151). The 44 non-biographical items were subjected to exploratory factor analysis with acceptable results indicating that the items included in the scales represent the constructs well.

The Cronbach's alpha coefficient was used as an indicator to check the internal consistency of whether the items that make up the scale belong together. According to Pallant (2005, 90), the Cronbach's alpha coefficient of a scale should be above 0.7 for the scale to be considered reliable for the sample. In this study, the Cronbach's alpha coefficient varied between .978 and .966 for the various scales, which indicates that the inter-item reliability is acceptable and that the scales can be considered reliable for the sample.

In order to test the suitability of the items in the questionnaire a pilot study was undertaken where 20 questionnaires were distributed to respondents at a campus not selected in the final 
survey. Fourteen questionnaires (70\%) were returned to the researcher. The average time taken to complete the survey in the pilot study was less than 20 minutes and the instructions were clearly understood. Consequently, as no significant problems were encountered in the completion of the pilot questionnaires, the researchers decided that it was not necessary to adjust the questionnaires.

Permission was granted to the researchers from the DHET to carry out the research at the three FET colleges in Mpumalanga. The Ethics Committee of the university also approved the study. The study was organised in such a way that the research process did not interrupt normal college activities and confidentiality of all concerned were respected. The researchers also endeavoured to protect participants from the risk of harm or from a situation where information gleaned could be used to their detriment.

\section{ANALYSIS OF THE DATA}

In order to determine the ranking of the most important sub-factor per first-order factor, respondents were asked to rank the three most important sub-factor per first-order factor in each of the sections $B, C, D$ and $E$.

Table 6: Rankings of items in Section B

\begin{tabular}{|c|c|c|}
\hline Most important items in leadership and setting direction (Section B) & $\begin{array}{l}\text { Number I } \\
\%\end{array}$ & $\begin{array}{l}\text { Mean I } \\
\text { Rank }\end{array}$ \\
\hline \multirow{2}{*}{$\begin{array}{l}\text { B8 ... creates high academic expectations amongst students - 1st, 2nd, } \\
\text { 3rd important summed }\end{array}$} & 115 & 3.30 \\
\hline & $42.40 \%$ & 7 \\
\hline \multirow{2}{*}{ B4 ... sets clear goals with targets - 1st, 2 nd, 3rd important summed } & 88 & 3.39 \\
\hline & $32.50 \%$ & 3 \\
\hline \multirow{2}{*}{$\begin{array}{l}\text { B7 ... creates high academic expectations amongst staff }-1 \text { st, } 2 \text { nd, 3rd } \\
\text { important summed }\end{array}$} & 84 & 3.53 \\
\hline & $31.00 \%$ & 1 \\
\hline \multirow{2}{*}{$\begin{array}{l}\text { B6 ... communicates the campus's goals to students - 1st, 2nd, 3rd } \\
\text { important summed }\end{array}$} & 80 & 3.15 \\
\hline & $29.50 \%$ & 8 \\
\hline \multirow{2}{*}{$\begin{array}{l}\text { B5 ... communicates the campus's goals to staff }-1 \text { st, } 2 \text { nd, 3rd } \\
\text { important summed }\end{array}$} & 77 & 3.47 \\
\hline & $28.40 \%$ & 2 \\
\hline \multirow{2}{*}{$\begin{array}{l}\text { B10 ... ensures that all activities are aligned to the shared vision of the } \\
\text { institution - 1st, 2nd, 3rd important summed }\end{array}$} & 73 & 3.31 \\
\hline & $26.90 \%$ & 5 \\
\hline \multirow{2}{*}{ B1 ... provides a clear vision - 1st, 2nd, 3rd important summed } & 70 & 3.34 \\
\hline & $25.80 \%$ & 4 \\
\hline \multirow{2}{*}{ B3 ... provides strategic direction - 1st, 2nd, 3rd important summed } & 70 & 3.31 \\
\hline & $25.80 \%$ & 5 \\
\hline \multirow{2}{*}{$\begin{array}{l}\text { B2 ... conducts a SWOT analysis to determine the needs of the campus } \\
-1 \text { st, } 2 \text { nd, 3rd important summed }\end{array}$} & 51 & 3.10 \\
\hline & $18.80 \%$ & 10 \\
\hline \multirow{2}{*}{$\begin{array}{l}\text { B9 ... obtains the support of stakeholders when developing the vision of } \\
\text { the institution - 1st, } 2 \text { nd, 3rd important summed }\end{array}$} & 49 & 3.11 \\
\hline & $18.10 \%$ & 9 \\
\hline
\end{tabular}

The data in Table 6 indicates that respondents ranked item B8 (creating high academic expectations among students) as the most important. However, the mean rank of item B8 placed 
it seventh position. It was only item B7 (creates high academic expectations amongst staff) which featured in the first three in both importance and mean ranks. The Alpha correlation coefficient was small but significant $(r=0.119 ; \mathrm{p}<0.05)$.

Table 7: Rankings of items in Section C

\begin{tabular}{|c|c|c|}
\hline Most important developing people items (Section C) & $\begin{array}{l}\text { Number I } \\
\%\end{array}$ & $\begin{array}{l}\text { Mean I } \\
\text { Rank }\end{array}$ \\
\hline \multirow[t]{2}{*}{ C2 ... motivates staff to perform better - 1st, 2 nd, 3rd important summed } & 147 & 3.27 \\
\hline & $54.60 \%$ & 3 \\
\hline \multirow{2}{*}{$\begin{array}{l}\text { C10 ... is knowledgeable about curriculum matters - 1st, } 2 \text { nd, 3rd } \\
\text { important summed }\end{array}$} & 95 & 3.35 \\
\hline & $35.30 \%$ & 1 \\
\hline \multirow{2}{*}{$\begin{array}{l}\text { C4 ... promotes continuous professional development for staff }-1 \text { st, 2nd, } \\
\text { 3rd important summed }\end{array}$} & 94 & 3.13 \\
\hline & $34.90 \%$ & 8 \\
\hline \multirow{2}{*}{$\begin{array}{l}\text { C6 ... provides a good example for staff to follow - 1st, 2nd, 3rd } \\
\text { important summed }\end{array}$} & 90 & 3.28 \\
\hline & $33,50 \%$ & 2 \\
\hline \multirow{2}{*}{$\begin{array}{l}\text { C8 ... manages staff performance to improve teaching - 1st, 2nd, 3rd } \\
\text { important summed }\end{array}$} & 75 & 3.15 \\
\hline & $27.90 \%$ & 7 \\
\hline \multirow{2}{*}{$\begin{array}{l}\text { C1 ... recognises individual staff accomplishments }-1 \text { st, } 2 \text { nd, 3rd } \\
\text { important summed }\end{array}$} & 65 & 3.24 \\
\hline & $24.20 \%$ & 4 \\
\hline \multirow{2}{*}{$\begin{array}{l}\text { C9 ... supports mentorship programmes for new staff - 1st, 2nd, 3rd } \\
\text { important summed }\end{array}$} & 56 & 2.87 \\
\hline & $20.80 \%$ & 10 \\
\hline \multirow{2}{*}{$\begin{array}{l}\text { C5 ... encourages feedback from staff on professional development } \\
\text { programmes - 1st, } 2 \text { nd, 3rd important summed }\end{array}$} & 45 & 3.22 \\
\hline & $16.70 \%$ & 5 \\
\hline \multirow{2}{*}{$\begin{array}{l}\text { C3 ... builds a relationship of trust amongst stakeholders }-1 \text { st, } 2 \text { nd, 3rd } \\
\text { important summed }\end{array}$} & 44 & 3.08 \\
\hline & $16.40 \%$ & 9 \\
\hline C7 ... maintains high visibility - 1st, 2nd, 3rd important summed & 37 & 3.20 \\
\hline
\end{tabular}

The data in Table 7 indicate that item C2 (motivates staff to perform better) is ranked first as most important while it is ranked $3^{\text {rd }}$ in mean rankings. Item C10 (is knowledgeable about curriculum matters) is ranked second most important and $1^{\text {st }}$ in mean score rankings. The Alpha correlation coefficient between the importance and mean was small and non-significant $(\mathrm{r}=0.067 ; \mathrm{p}>0.05)$.

Table 8: Rankings of items in Section D

\begin{tabular}{|c|c|c|}
\hline Most important organisational culture items (Section D) & $\begin{array}{l}\text { Number I } \\
\%\end{array}$ & $\begin{array}{l}\text { Mean I } \\
\text { Rank }\end{array}$ \\
\hline \multirow{2}{*}{$\begin{array}{l}\text { D9 ... inspires staff to work together as a team - 1st, 2nd, 3rd } \\
\text { important summed }\end{array}$} & 115 & 3.26 \\
\hline & $42,30 \%$ & 1 \\
\hline \multirow{2}{*}{$\begin{array}{l}\text { D4 ... promotes continuous improvement in all academic processes - } \\
\text { 1st, 2nd, 3rd important summed }\end{array}$} & 88 & 3.21 \\
\hline & 32,40 & 2 \\
\hline \multirow{2}{*}{$\begin{array}{l}\text { D2 ... encourages shared decision making - 1st, 2nd, 3rd important } \\
\text { summed }\end{array}$} & 86 & 3.06 \\
\hline & $31.60 \%$ & 7 \\
\hline \multirow{2}{*}{$\begin{array}{l}\text { D1 ... shapes the organisational culture of the campus - 1st, 2nd, 3rd } \\
\text { important summed }\end{array}$} & 77 & 3.06 \\
\hline & $28.30 \%$ & 7 \\
\hline \multirow{2}{*}{$\begin{array}{l}\text { D10 ... encourages the use of technology to enhance instruction - 1st, } \\
\text { 2nd, 3rd important summed }\end{array}$} & 76 & 3.19 \\
\hline & $27.90 \%$ & 3 \\
\hline D6 ... provides incentives to staff to encourage high student & 75 & 2.80 \\
\hline
\end{tabular}




\begin{tabular}{|c|l|l|}
\hline Most important organisational culture items (Section D) & $\begin{array}{l}\text { Number I } \\
\%\end{array}$ & $\begin{array}{l}\text { Mean I } \\
\text { Rank }\end{array}$ \\
\hline achievement - 1st, 2nd, 3rd important summed & 10 \\
\hline $\begin{array}{l}\text { D3 ... distributes tasks to staff effectively - 1st, 2nd, 3rd important } \\
\text { summed }\end{array}$ & $27.69 \%$ & 3.09 \\
\hline $\begin{array}{l}\text { D5 ... implements processes to create an orderly campus } \\
\text { environment - 1st, 2nd, 3rd important summed }\end{array}$ & $26.80 \%$ & 5 \\
\hline $\begin{array}{l}\text { D7 ... provides incentives to students to encourage high achievement } \\
\text { - 1st, 2nd, 3rd important summed }\end{array}$ & 72 & 3.13 \\
\cline { 2 - 3 } $\begin{array}{l}\text { D8 ... networks with the wider community - 1st, 2nd, 3rd important } \\
\text { summed }\end{array}$ & $26.50 \%$ & 4 \\
\cline { 2 - 3 } & $23.50 \%$ & 3.11 \\
\hline
\end{tabular}

The data in Table 8 indicates that item D9 was ranked first as most important as well as having the $1^{\text {st }}$ mean rank. Also Item D4 was placed second in both importance and mean ranking. Thus inspiring staff to work together and promoting continuous improvement in all academic processes was also deemed as important with respect to developing a suitable organisational culture. The Alpha correlation coefficient was positive, small and nonsignificant $(r=0.067 ; \mathrm{p}>0.05)$.

Table 9: Rankings of items in Section $\mathrm{E}$

\begin{tabular}{|c|c|c|}
\hline Most important instructional management items (Section E) & $\begin{array}{l}\text { Number I } \\
\%\end{array}$ & $\begin{array}{l}\text { Mean I } \\
\text { Rank }\end{array}$ \\
\hline \multirow{2}{*}{$\begin{array}{l}\text { E7 ... provides resources for teaching - 1st, 2nd, 3rd important } \\
\text { summed }\end{array}$} & 130 & 3.22 \\
\hline & $47.80 \%$ & 4 \\
\hline \multirow{2}{*}{$\begin{array}{l}\text { E1 ... establishes a focus on teaching - 1st, 2nd, 3rd important } \\
\text { summed }\end{array}$} & 111 & 3.31 \\
\hline & $40.80 \%$ & 1 \\
\hline \multirow{2}{*}{$\begin{array}{l}\text { E3 ... manages poor staff performance }-1 \text { st, } 2 \text { nd, 3rd important } \\
\text { summed }\end{array}$} & 101 & 2.98 \\
\hline & $37.10 \%$ & 9 \\
\hline \multirow{2}{*}{$\begin{array}{l}\text { E6 ... monitors student academic progress - 1st, 2nd, 3rd } \\
\text { important summed }\end{array}$} & 83 & 3.23 \\
\hline & $30.50 \%$ & 3 \\
\hline \multirow{2}{*}{$\begin{array}{l}\text { E2 ... provides instructional support to staff - 1st, 2nd, 3rd } \\
\text { important summed }\end{array}$} & 75 & 3.12 \\
\hline & $27.60 \%$ & 6 \\
\hline \multirow{2}{*}{$\begin{array}{l}\text { E8 ... provides feedback to staff after monitoring teaching } \\
\text { activities - 1st, } 2 \text { nd, 3rd important summed }\end{array}$} & 64 & 3.09 \\
\hline & $23.50 \%$ & 7 \\
\hline \multirow{2}{*}{$\begin{array}{l}\text { E4 ... ensures staff preparedness for effective instruction - 1st, } \\
\text { 2nd, 3rd important summed }\end{array}$} & 61 & 3.03 \\
\hline & $22.40 \%$ & 8 \\
\hline \multirow{2}{*}{$\begin{array}{l}\text { E9 ... ensures that instructional time is protected }-1 \text { st, } 2 \text { nd, 3rd } \\
\text { important summed }\end{array}$} & 53 & 3.27 \\
\hline & $19.50 \%$ & 2 \\
\hline \multirow{2}{*}{$\begin{array}{l}\text { E10 ... uses data to improve campus performance - 1st, 2nd, 3rd } \\
\text { important summed }\end{array}$} & 52 & 3.21 \\
\hline & $19.10 \%$ & 5 \\
\hline \multirow{2}{*}{$\begin{array}{l}\text { E5 ... observes classroom instruction - 1st, 2nd, 3rd important } \\
\text { summed }\end{array}$} & 36 & 2.98 \\
\hline & $13.20 \%$ & 9 \\
\hline
\end{tabular}

The data in Table 9 points to item E1 as being placed second in importance and $1^{\text {st }}$ in mean ranking. Thus establishing a focus on teaching is important when concerned with the management of instructional programmes. The correlation coefficient was positive, small and non-significant ( $\mathrm{r}=0.081 ; \mathrm{p}>0.05)$. 
The four highest achieving campuses and four lowest achieving campuses were coded using 1 for the lowest achieving campuses in each FET and 2 for the highest achieving campuses. In this way two independent groups were formed as one cannot belong to both; they are independent of one another. The four first-order leadership factors were then tested via the independent group t-test to determine statistically significant differences between the two groupings. The results are displayed in Table 10.

Table 10: Significance of differences between the four highest and four lowest achieving campus groups in the FET Colleges

\begin{tabular}{|c|c|c|c|c|}
\hline Factor & Group & Mean & $\begin{array}{l}\text { t-test } \\
\text { (p-value) }\end{array}$ & $\begin{array}{l}\text { Effect } \\
\text { size (r) }\end{array}$ \\
\hline \multirow[t]{2}{*}{ Leadership and setting direction (FB1) } & Lowest & 2.36 & \multirow[t]{2}{*}{$0.000^{\star *}$} & \multirow[t]{2}{*}{0.53} \\
\hline & Highest & 4.11 & & \\
\hline \multirow[t]{2}{*}{ Leadership and developing people (FC1) } & Lowest & 2.19 & \multirow[t]{2}{*}{$0.000^{\star *}$} & \multirow[t]{2}{*}{0.61} \\
\hline & Highest & 4.07 & & \\
\hline \multirow{2}{*}{$\begin{array}{l}\text { Leadership and developing organisational } \\
\text { culture (FD1) }\end{array}$} & Lowest & 2.03 & \multirow[t]{2}{*}{$0.000^{\star \star}$} & \multirow[t]{2}{*}{0.66} \\
\hline & Highest & 3.99 & & \\
\hline \multirow{2}{*}{$\begin{array}{l}\text { Leadership and managing the instructional } \\
\text { programme (FE1) }\end{array}$} & Lowest & 2.05 & \multirow[t]{2}{*}{$0.000^{\star \star}$} & \multirow[t]{2}{*}{0.62} \\
\hline & Highest & 4.06 & & \\
\hline
\end{tabular}

* = Statistically significant at the $5 \%$ level $(p>0.01$ but $p<0.05)$

** $=$ Statistically significant at the $1 \%$ level $(p<0.01)$

Effect size: Small: $r=0.1$ to 0.29 ; Moderate: $r=0.3$ to 0.49 ; Large: $r=0.50+$

The grouping of the independent variables into the four highest and four lowest achieving campuses has resulted in statistically significant differences being present in each one of the four first-order factors. In each case the higher achieving group had a statistically significantly higher score in the leadership factor than the lower group had. The effect sizes were large in each case as the grouping was manipulated so that the high achieving campuses and low achieving campuses would belong together. Thus the campuses which achieved the higher factor scores believe to a greater extent that the four leadership factors (FB1 to FE1) influence student achievement than the lower achieving group believe it. The practical significance of the large effect size could well be that a positive belief in ability leads to a positive belief in leadership factors and FET college campuses with good examination results are likely to have a climate and culture where people can be developed to their maximum potential.

\section{Student achievement as measured via the NCV examination}

The student achievement data was associated with the situation of the college with students at rural colleges performing significantly better than students at urban colleges. However, the data collection may be slightly inaccurate as some respondents were confused between urban and rural situations. The College $\mathrm{C}$ had the highest mean scores and differed significantly from College A and College B. Teaching qualification was also associated with student achievement 
in that the respondents with the highest teaching qualification at an FET College had the best student performance.

Multiple regression indicated that the best predictor of the NCV examination was leadership associated with managing the instructional programme (FE1) followed by leadership and developing an organisational culture (FD1). The managing the instructional programme (FE1) is similar to what has been named instructional leadership.

The multiple linear regression model confirmed that effective leadership in an FET college campus to influence student achievement was founded on four factors, as identified in the theoretical framework, namely managing the instructional programme, developing an organisational culture, setting direction and developing people which are all geared towards improving student academic performance.

The ranking data obtained from sections B11, C11, D11 and E11 of the questionnaire aided the researcher to identify the sub-factor that respondents perceived to be the most important for each of the four underlying factors. This is reflected in Table 11.

Table 11: Each factor with the corresponding sub-factor with the highest mean score

\begin{tabular}{|l|l|}
\hline Factor & Sub-factor with highest mean score \\
\hline FD1 - developing an organisational culture & D9 ... inspires staff to work together as a team \\
\hline FB1 - setting direction & B7 ... creates high academic expectations amongst staff \\
\hline FC1 - developing people & C10 ... is knowledgeable about curriculum matters \\
\hline FE1 - managing the instructional programme & E1 ... establishes a focus on teaching \\
\hline
\end{tabular}

For each of the four leadership factors, College C obtained the highest mean scores, followed by College B and College A. This ranking correlated exactly with the academic performance of the three colleges.

The analysis of the four highest achieving campuses indicated an average mean score of 3.80 for the leadership of their campus managers while the four lowest achieving campuses rated the leadership of their campus managers 26 per cent lower with an average mean score of 2.48 .

Using the multiple regression analysis model with the average percentages obtained in the 2013 NCV examination as the outcome and the four leadership factors as predictors the following equation to predict student achievement in NCV examinations was derived:

Ach.inNCV $=b_{0}+b_{1} F B 1+b_{2} F C 1+b_{3} F D 1+b_{4} F D 1$

According to this model, the most important predictors in student achievement in the NCV 
examination is leadership in managing the instructional programme.

Table 12: The coefficients in the regression model with dependent variable effective leadership in a FET college

\begin{tabular}{|l|l|l|l|l|}
\hline \multirow{2}{*}{ Model } & Standardized Coefficients & \multirow{2}{*}{ t } & Sig. \\
\cline { 3 - 5 } & Beta & -.321 & .748 \\
\hline \multirow{1}{*}{1} & (Constant) & & 114.761 & .000 \\
\cline { 2 - 5 } & FB1. Setting direction & .269 & 87.834 & .000 \\
\cline { 2 - 5 } & FC1. Developing people & .244 & 86.668 & .000 \\
\cline { 2 - 5 } & $\begin{array}{l}\text { FD1. Developing an Organisational } \\
\text { Culture }\end{array}$ & .272 & 101.154 & .000 \\
\cline { 2 - 5 } & $\begin{array}{l}\text { FE1. Managing the instructional } \\
\text { programme }\end{array}$ & .273 & & \\
\hline
\end{tabular}

The data in Table 12 indicate that FE1 (leadership and managing the instructional programme) has the highest beta value (0.273) but that developing an organisational culture virtually has the same beta value (0.272). Thus as FE1 increases by one standard deviation unit (1.11) the outcome namely effective leadership (F2.0) increases by 0.273 units. The same can be said of developing an organisational culture. Hence FEI and FD1 are virtually equally important in the prediction of F2.0 namely effective leadership in influencing student achievement in FET college campuses in Mpumalanga. Setting direction (FB1) would be the third most important predictor followed by FC1 namely developing people. It is likely that in establishing an organisational culture to influence student achievement that the leader will pay particular attention to managing the instructional programme in order to improve the academic performance of students. Hence FD1 and FE1 will be closely aligned and jointly influence one another in relation to student achievement.

The multiple linear regression model indicated that effective leadership in an FET College to influence student achievement (F2.0) is founded on four factors namely managing the instructional programme (FE1), developing an organisational culture (FD1), setting direction (FB1) and developing people (FC1) which are all geared towards improving student academic performance. These four first-order factors all had normal distribution of data and high reliability coefficients.

\section{RESULTS AND DISCUSSION}

Researchers such as Cotton (2003) and Hallinger (2003) have consistently found that highachieving institutions are successful, in part, because their leaders regularly share their expectations of high performance with students and staff. FET college campus managers need to create high performance expectations for both staff and students and then support initiatives to achieve these expectations. If the vision of the FET college campus is to improve student 
achievement, the campus manager needs to not only communicate this vision but also demonstrate that he supports this vision by appropriate actions such as leading staff development, monitoring and evaluating instruction, and co-ordination of student achievement improvement plans.

The multiple linear regression model indicated that effective leadership in an FET college to influence student achievement is founded on four factors namely managing the instructional programme, developing an organisational culture, setting direction and developing people which are all geared towards improving student academic performance.

According to the multiple regression model, the most important predictors in student achievement in the NCV examination is the leadership role of the campus manager in managing the instructional programme (instructional leadership), followed by developing an organisational culture, then setting direction and lastly developing people. In each of these leadership roles, the study identified the most important sub-factor as perceived by the respondents.

a) According to the respondents, for the leadership role linked to setting direction, the most important sub-factor (mean score), from the 10 identified in the study, was that the campus manager should create high academic expectations amongst staff.

b) For the leadership role linked to developing people, the most important sub-factor, was that the campus manager should be knowledgeable about curriculum matters.

c) For the leadership role linked to organisational culture, the most important sub-factor was that the campus manager inspire staff to work together as a team.

d) For the leadership role linked to instructional management, the most important sub-factor, was that the campus manager should establish a focus on teaching.

An analysis of all four constructs across all 40 sub-factors, indicates that the three sub-factors with the highest mean scores were:

- Most important: That the campus manager should create high academic expectations amongst staff.

- $\quad$ Second most important: That the campus manager should communicate the campus's goals to the staff.

- $\quad$ Third most important: That the campus manager should sets clear goals with targets. 
The analysis of the four highest achieving campuses indicated an average mean score of 4.06 for the leadership of their campus managers while the four lowest achieving campuses rated the leadership of their campus managers 40 per cent lower with an average mean score of 2.06. This is arguably the most important finding of this study as it provides tangible evidence of the link between the leadership role of the campus manager and student achievement.

\section{RECOMMENDATIONS}

As a result of the above findings, both from the literature review as well as from the empirical findings, the following recommendations are made in response to how the leadership roles of campus managers can be developed to improve student achievement in FET colleges.

Knowledge of the four categories of leadership, as identified in the theoretical framework, namely managing the instructional programme, developing an organisational culture, setting direction and developing people which are all geared towards improving student academic performance, would empower campus managers in their role of leadership. An understanding of the 40 sub-factors identified in the study can provide campus managers with the necessary skills that are linked to high quality teaching and learning and improved student performance. The formation of a provincial community of practice or community of learning for campus managers is highly recommended. This forum can meet regularly, possibly once a month, to discuss matters of common interest, share best practices and receive training. One or two of the 40 sub-factors, identified in this study, could form part of the agenda of these developmental meetings.

The researchers believe that expertise of the FET sector lies within the FET sector, as shown by the top-performing campus managers, and this expertise must be optimally utilised in the development process of campus managers.

\section{CONCLUSION}

One of the most pressing challenges facing South Africa, post democracy, is the high levels of unemployment, especially among the youth. It is argued that FET colleges are uniquely positioned to provide unemployed youth with intermediary and higher level education and training that can lead directly into employment, provided that the education and training is of high quality. Improving the quality of FET colleges, and consequently student achievement, is essential if FET colleges are to meet the demands of skilling the youth for employment. Consequently, the study sought to identify successful leadership roles and practices in campus managers and to better understand how these leadership roles and practices can improve student 
achievement in FET colleges in South Africa.

In trying to achieve this aim, a literature review of leadership and student achievement in educational institutions was undertaken. The recurring themes of the literature review were reduced to four categories of leadership roles. These four categories, namely, setting direction, developing people, developing the organisational culture and managing the instructional programme formed the theoretical framework of the study. This was followed by empirical research to garner the perspectives of academic staff regarding the way in which campus managers employ leadership roles to improve student academic achievement in their colleges. The data obtained from 357 academic staff at all three FET colleges in the province of Mpumalanga was then analysed and interpreted.

Arguably, the most significant finding in this study is the leadership roles played by campus managers of poor performing campuses compared to high performing campuses. The leadership of campus managers of high performing campuses were rated at a significantly higher level than campus managers of poor performing campuses. This suggests that there is a tangible link between the leadership role of the campus manager and student achievement. Replicating the leadership roles of campus managers of high performing colleges, especially as the contexts surrounding the majority of colleges in South Africa are very similar, has the potential to impact on improving student achievement. A possible further research topic, linked to this study, which could be considered is the monitoring and evaluation role of campus managers in improving student achievement at FET colleges. Finally, the researchers are of the opinion that the four categories of leadership roles identified by the study can be used by campus managers to improve student achievement.

\section{REFERENCES}

Bryman, A. 2007. Effective leadership in higher education: Summary of findings. London: Leadership Foundation for Higher Education.

Bush, T. 2008. Leadership and management development in education. Nottingham: Sage Publications.

Bush, T. and M. Coleman. 2000. Educational management research and practice: Leadership and strategic management in education. London: Paul Chapman.

Cloete, N., H. Perold and J. Papier. 2012. Shaping the future of South Africa's youth: Rethinking postschool education and skills training. Wynberg: African Minds.

Cotton, K. 2003. Principals and student achievement: What the research says. Virginia: Association for Supervision and Curriculum Development.

Danielson, C. 2002. Enhancing student achievement: A framework for school improvement. Virginia: Association for Supervision and Curriculum Development.

Department of Higher Education and Training. 2010. Systemic audit of Further Education and Training colleges in the Eastern Cape. Pretoria: Government Printers.

Department of Higher Education and Training. 2013. White Paper for Post-School Education and 
Training: Building an expanded, effective and integrated post-school system. Pretoria: Government Printers.

Department of Higher Education and Training. 2014. Correspondence on NCV certification rates for colleges in Mpumalanga. Nelspruit. Government Printers.

Deshmukh, A. V. and A. P. Naik. 2010. Educational management. Mumbai: Himilaya.

DHET see Department of Higher Education and Training.

Grogan, M. 2013. Jossey-Bass reader on educational leadership. 3rd edition. New Jersey: Wiley.

Hallinger, P. 2003. Leading educational change: Reflections on the practice of instructional and transformational leadership. Cambridge: Routledge.

Jackson, R. J. 2013. Never underestimate your teachers: Instructional leadership for excellence in every classroom. Virginia: Association for Supervision and Curriculum Development.

Leithwood, K., C. Day, P. Sammons, A. Harris and D. Hopkins. 2006. Successful school leadership: What it is and how it influences pupil learning. Nottingham. University of Nottingham.

Leithwood, K. and K. S. Louis. 2011. Linking leadership to student learning. New Jersey: Jossey-Bass.

Leithwood, K., K. S. Louis, K. L. Wahlstrom and S. E. Anderson. 2004. Review of research: How leadership influences student learning. Minnesota, University of Minnesota Press.

Leithwood, K., K. S. Louis, K. L. Wahlstrom and S. E. Anderson. 2010. Investigating the links to improved student learning: Final report of research findings. Minnesota: University of Minnesota Press.

Marzano, R. J., T. Waters and B. A. McNulty. 2005. School leadership that works: From research to results. Virginia: ASCD.

McCaffery, P. 2010. The higher education manager's handbook: Effective leadership and management in universities and colleges. New York: Routledge Falmer.

Middlewood, D. and J. Lumby. 2013. Strategic management in schools and colleges. London: Sage Publications.

OECD see Organisation for Economic Co-operation and Development.

Organisation for Economic Co-operation and Development report. 2011. http://www.oecd.org/edu/ school leadership (accessed 1 July 2014).

Pallant, J. 2005. SPSS Survival manual. 2nd edition. Sydney: Allen \& Unwin.

Republic of South Africa. 2013. National Development Plan 2030 - Our future: Make it work. Pretoria: Government Printers.

RSA see Republic of South Africa.

Stronge, J. H., H. B. Richard and N. Catano. 2008. Qualities of effective principals. Virginia: Association for Supervision and Curriculum Development.

Stronge, J. H., X. Xu and L. M. Leeper. 2013. Principal evaluation: Standards, rubrics, and tools for effective performance. Virginia: Association for Supervision and Curriculum Development. 